\title{
Racial Diversity and Union Organizing in the United States, 1999-2008
}

\author{
John-Paul Ferguson \\ Stanford University
}

\begin{abstract}
Does racial diversity make it harder to form a union? Case studies give conflicting answers, and little large-scale research on the question exists. Most quantitative research on race and unionization studies trends in membership rather than the outcome of specific organizing drives, and assumes that the main problem is mistrust between workers and unions, paying less attention for example to the role of employers. I explore the role of racial and ethnic diversity in the outcomes of nearly 7,000 organizing drives launched between 1999 and 2008. By matching the National Labor Relations Board's information on union activity with the Equal Employment Opportunity Commission's surveys of large establishments, I reconstruct the demographic composition of the work groups involved in each mobilization. I find that more diverse establishments are less likely to see successful organizing attempts. However, I find little evidence that this is because workers are less interested in voting for unions. Instead, I find that the organizers of more diverse units are more likely to give up before such elections are held. Furthermore, this higher quit rate can be explained best by the other organizations involved in the organizing drive. In particular, employers are more likely to be charged with unfair labor practices when the unit in question is more racially diverse. This effect persists when controlling for heterogeneity among industries, unions and regions.
\end{abstract}




\section{Introduction}

Does racial diversity make it harder to form a union? Most work by industrial relations scholars (Sayles \& Strauss 1953, Dunlop 1958), labor sociologists (Nelson 2001, Clawson 2003, Fantasia \& Voss 2004) and historians (Lichtenstein 2002) presumes that it does. Unions' histories of racial conflict among and beyond their own memberships are well documented. Surveys of union members tend to find less trust and less union commitment among more diverse groups of employees (Bacharach \& Bamberger 2004). Such patterns are worrisome because, given the past and projected changes in the ethnic composition of the American workforce, unions that want to grow must build bridges to workers who differ from their existing members. The difficulty of building such bridges is often cited as a key challenge facing contemporary unions (Clawson 2003, Milkman \& Voss 2004, Rosenfeld \& Kleykamp 2009).

There has been surprisingly little empirical research into racial diversity's effects on union formation, though, and what work does exist has two limitations. First, "Much of the literature on blacks and organized labor is dated, historical, or both" (Rosenfeld \& Kleykamp 2012, p. 1462). Second, it focuses on the problem of building trust and solidarity among the potential union members, to the exclusion of other organizational actors. Taken together, these two limitations bias our thinking about the effects that racial and other ascriptive differences may have on union organizing, in two ways. First, there have been tremendous changes in unions' attitude toward female and minority workers over the years, accompanied by large changes in union memberships (Isaac, McDonald \& Lukasik 2006, Milkman 2006, Rosenfeld \& Kleykamp 2009, Rosenfeld \& Kleykamp 2012). Unions today are among the most integrated organizations in the United States (Freeman \& Rogers 1999). Yet there have been few analyses of whether racial diversity affects union formation the same ways today as it did in the past. Second, the focus on trust, solidarity and other dynamics among workers presumes that racial diversity matters 
most during union-representation elections, where workers' votes decide the outcome (Heneman \& Sandver 1983, Barling, Fullagar \& Kelloway 1992). But America's industrial-relations regime has been transformed in recent decades (Kochan, Katz \& McKersie 1986, Rosenfeld 2014), eroding unions' organizing capacities even as the older ethnic animus has moderated. Employers increasingly take the initiative in fighting union-organizing campaigns, employing means legal and not to stymie organizers (Freeman \& Kleiner 1990, Cohen \& Hurd 1998, Bronfenbrenner 2009). Unions have tried to revamp their organizing routines, focusing as much on convincing employers not to resist the union's efforts as on mustering votes among the workers themselves (Voss \& Sherman 2000, Martin 2008a). These shifts in employer and union tactics mean that many organizing drives are decided before workers ever get to express their preferences (Ferguson 2008). Yet the role that racial diversity has on those organizational actors, who can clearly influence such campaigns, has largely been ignored.

In this article, I explore the effects of racial diversity on the success at various stages of a union organizing drive. I employ unique data that combines a decade of the National Labor Relations Board's records of union representation cases with surveys of workforce composition from the Equal Employment Opportunity Commission. I examine not only whether unions win representation elections but also whether they go through with elections in the first place, as opposed to giving up and withdrawing their petitions.

I find that the work groups that win union representation are less racially diverse than the population of work groups that initially filed election petitions. This is consistent with existing assumptions. However, I find no evidence that this winnowing of diverse work groups happens through the representation vote. If anything, more diverse work groups are more likely to vote for unionization. Instead, organizing drives among more racially diverse groups are more likely to end in withdrawal before 
the election takes place.

I also find that the actions of the employers and unions influence the likelihood of such withdrawals. Most strikingly, employers are more likely to commit unfair labor practices - to intimidate and fire employees for their union activity - when a work group is more racially diverse. This propensity persists in models that control for differences among the geographic regions, unions and industries involved in these drives, and for endogeneity in the choice to withdraw before the vote.

These findings make three contributions. First, they reinforce the argument that contemporary union organizing is better understood as a multi-stage organizational process than as a discrete instance of collective action (Ferguson 2008). Focusing solely on representation elections skews our understanding of labor-union formation, given the multiple opportunities for failure and self-selection inherent in the process. Second, the different response by employers to campaigns by more diverse workers is in line with research into the repression of collective action (Gamson 1990, Soule \& Davenport 2009, Davenport, Soule \& Armstrong II 2011), and highlights a type of hurdle that unions share with other types of social movements. Third, the greater influence of employers and (to a lesser extent) unions in the earlier, less formalized and regulated parts of the campaign jibes with studies of when and how collective action influences formal organizational structures (Burstein, Einwohner \& Hollander 1995, Burstein \& Linton 2002, King, Cornwall \& Dahlin 2005). Thus, in addition to updating our understanding of the challenges (and opportunities) that racial diversity poses for new union organizing, this study connects unions' seemingly idiosyncratic problems to the larger study of mobilization for social change. 


\section{Race and union organizing}

American labor unions' fraught racial history is well documented. Well into the 1930s, most unions reflected the racial prejudices and practices of American society, reserving jobs for members of preferred ethnic and racial groups, and often clashing bitterly with the black or immigrant workers that employers sometimes used to break strikes (Zeiger 1986, Olzak 1989, Cohen 1990). The industrial unions of the CIO bucked this trend during the depression and war years, explicitly trying to build coalitions across groups of workers of different races (Zeiger 1995, Halpern 1997, Stromquist \& Bergman 1997). In the wake of the Civil Rights movement, black Americans joined unions in unprecedented numbers (Isaac, McDonald \& Lukasik 2006), even as persistent discrimination by some unions, particularly in the building trades, spurred early government efforts at affirmative action (Schuwerk 1972, Pedriana \& Stryker 1997).

While acknowledging the strides that unions have made in integrating their memberships (Freeman \& Medoff 1984), labor scholars point out unions' continuing difficulties with building coalitions across racial and ethnic lines (Clawson 2003). Most such calls for building a "culture of inclusion" (Fletcher Jr. \& Hurd 2000) focus on the racial and ethnic divides between unions' existing members and unorganized workers (Lüthje \& Scherrer 2001, Nissen 2002, Yates 2005, Wilson 2008). Such critiques are often juxtaposed with case studies in which unions have built cross-racial coalitions to enroll new members. The most prominent example is probably the SEIU's Justice for Janitors campaign (Milkman 2006, Widener 2008, Yu 2008), with other examples in meatpacking (Brueggemann \& Brown 2003), the hotel industry (Sharpe 2004), and health care (Clawson 2003). Such case studies often focus on black and white workers, but the cases on the West Coast in particular dovetail with analyses of unions' assimilation of newer, typically latino, workers (Fletcher Jr. \& Hurd 2000, Reitz \& Verma 2004, Yu 2008). 
Case studies offer details and inspiration but can say little about broader trends. For those, larger-scale studies have presented some suggestive findings. Isaac, McDonald \& Lukasik (2006) detail how and when minority membership in unions rose in the wake of the Civil Rights movement, and Rosenfeld \& Kleykamp (2012) find that blacks have been more likely to join unions where the potential wage benefit and protection from arbitrary managerial authority are greater. Latinos and other immigrant groups join unions at higher rates the longer they are resident in the country, even though the wage premiums from doing so have fallen over time (Reitz \& Verma 2004, Rosenfeld \& Kleykamp 2009), but their membership rates overall still lag black and white workers. Blacks tend to join unions at higher rates than whites, even when controling for differences in education, industry, and occupation (Freeman \& Medoff 1984, DeFreitas 1993, Rosenfeld \& Kleykamp 2009). Studies such as these give us rich detail about aggregate trends in minority unionization over time but, because they draw on surveys that ask about current union membership, they cannot directly investigate the role that racial diversity might play in specific union-organizing efforts.

A focus on diversity's role within such efforts is important because, otherwise, it is ambiguous what a rising share of minority members implies about the dynamics of diversity in labor unions. A national union could become more racially diverse in several ways. It could add minority workers to its existing locals, as for example the United Autoworkers did when black workers were added to the auto companies' assembly lines (Milkman 1987, Lichtenstein 1995). It could enroll new workers in new, heterogeneous union locals while preserving older, homogeneous ones. The Brotherhood of Firemen and Oilers for example took this approach when they expanded from the furnace and machine rooms of hospitals and other large institutions and organized the more diverse janitorial staffs. Finally, the union could form new, homogeneous, minority locals, thus preserving unit-level segregation even as union diversity rises. The Longshoremen on the east coast tried such a tactic for many years, forming lo- 
cals of black dockers in the south, Italian dockers in New Jersey and so on. In other words, while the rising share of minority members that studies like Isaac, McDonald \& Lukasik's (2006) and Rosenfeld \& Kleykamp's (2012) document is encouraging, we would interpret that trend very differently if most of those new members were enrolled in segregated locals. Given that occupational segregation has remained stagnant in recent years even as establishment-level segregation has declined (Tomaskovic-Devey, Zimmer, Stainback, Robinson, Taylor \& McTague 2006), there are grounds for such concern.

The other angle from which the relationship between diversity and unionization has been studied is research into workers' opinions about unions. Sayles \& Strauss (1953) and Perline \& Lorenz (1970), for example, both found that participation in union activities was greatest among ethnically homogeneous workgroups; more recently, Iverson \& Kuruvilla (1995) found that workers in homogeneous units have greater satisfaction with and loyalty to their unions. The advantage of opinion studies is that they can include workers who are not (but might become) union members. Studies of members and non-members have less definitive findings. Bacharach \& Bamberger (2004) find mixed results regarding union trust and commitment among a random sample of non-exempt workers and review similar, sometimes contradictory, results. In one of the few prior studies that has compared organizing outcomes on this dimension, Milkman (1993) found that win rates were highest in units that were evenly split between men and women. There is suggestive evidence therefore that unit heterogeneity plays a different role in nascent unions than in established ones, but there has been little speculation about the mechanisms involved. Virtually all of these studies take an essentially group-psychological approach (Barling, Fullagar \& Kelloway (1992) review prior work), presuming that diversity reduces the likelihood of unionization insofar as it reduces trust and commitment among employees who must engage in costly collective action. 
Such a presumption echoes the research on diversity and work-group performance (Williams \& O'Reilly 1998, van Knippenberg \& Schippers 2007). In its focus on the dynamics within groups, though, this psychological approach downplays or ignores the organizational dimension of union organizing drives. There is thus a gap in our understanding of diversity's role in this process. We have few large-scale studies of diversity's impact on union formation, and we have little theory about why diversity might matter, save that it makes workers less likely to trust unions or one another. This gap is important, because, as I discuss below, ignoring the organizational, processual nature of the organizing drive encourages us to place more weight on individual workers' choices and opinions than we perhaps should. Accordingly, I next review the stages of the union-organizing process and hypothesize the role that diversity might play at different stages.

\section{Stages of the organizing drive}

While most work on union organizing drives focuses on the outcomes of representation

elections (Heneman \& Sandver 1983, Riddell 2004, Tope \& Jacobs 2009), forming a union in the United States is a multi-step process. There are many hurdles that must be cleared, and different actors influence the outcome at different stages. Narrative accounts of union organizing implicitly describe a multi-step process, emphasizing for example how building the initial contacts between a union and potential members requires different skills than contesting a representation election or bargaining with an employer (Rooks 2004, Yu 2008).

Figure 1 shows a schematic version of the organizing process (McGuiness \& Norris (1986) describe this process in detail). Organizing begins with a "card drive," the period during which organizers develop initial contacts with employees and canvas for support. The card drive is probably the highest hurdle of the entire process, insofar as there is the most uneven support for the union among the workforce and little 
collective capacity has been developed to respond to counter-moves by the employer. It is hard to know the failure rate of card drives because the NLRB only opens case files for organizing drives once the card drive has succeeded-hence my graying out as unobserved this stage in figure 1. The groups that pass through the card drive have only begun the process; other hurdles, which can be observed and modeled, remain.

A card drive succeeds when the organizers collect, from at least 30 percent of the workers in the proposed bargaining unit, signed cards that state the workers' interest in an NLRB-supervised secret-ballot election, in which they can vote whether to have the union as their representative for collective bargaining with their employer. The NLRB then rules on the appropriateness of the proposed unit and any other challenges. Assuming that the board goes forward with the unit as suggested or modified, the parties come to an agreement about the type and date of election. Within seven weeks on average after the petition filing, the NLRB supervises the election; a simple majority of votes cast wins. If the union wins and no objections are sustained, then the NLRB certifies the union as the employees' representative, and the employer is obligated to bargain "in good faith" with the union for at least one year. The goal of such bargaining is a formal contract governing the pay and conditions of employment, which typically runs for three years. ${ }^{1}$

[Figure 1 about here.]

\footnotetext{
${ }^{1}$ Figure 1 shows the procedure for forming a union through the NLRB's election system. This is not the only way to form a union local. At any time, a group of employees, a union and an employer can come to an agreement that the employer will recognize and bargain with the union, without having to invite the NLRB in. While rare, such "voluntary recognition" has received much attention in recent years, because many unions have acknowledged that in a more hostile political and economic environment they cannot simply rely on the NLRB (Fantasia \& Voss 2004, Bronfenbrenner \& Hickey 2004). Many of the most high-profile organizing successes of the last twenty years have come through strategic campaigns that bypass the election procedure. I nonetheless focus on the election process here, for two reasons. First, there is no systematic data on voluntary recognition, so we do not know how common such drives are and how many employees they affect (But see Brudney (2005) and Martin (2008b) for attempts). Second, the election process, flawed as it is, is still the main legal recourse for employees who do not have their employer's support or at least neutrality in organizing. Understanding the hurdles and outcomes of the election process is still important for large numbers of working people.
} 
An inherent feature of this process is that hurdles produce sample selection. Workers can only vote for a union if the election takes place. The organizing drive can break down at any of the stages shown in figure 1: the card drive can sputter out, the organizers can give up and withdraw their petitions before the election, or the vote could go against the union. Most quantitative studies of union organizing generalize from the election results, ignoring earlier stages of the organizing drive (Heneman \& Sandver 1983, Riddell 2004). Doing so can distort inferences about how different actions influence the process, though. For example, Ferguson (2008) found that employers' unfair labor practice charges (ULPs, described in more detail below) have little effect on election outcomes but make it substantially more likely for unions to withdraw their election petitions before a vote can be held.

This description of the organizing process is sufficient to demonstrate that the election, which has often been treated as the hurdle by which an organizing drive succeeds or fails and where the employees have the most influence, is the capstone of a longer process that has already selected out many potential bargaining units. To understand what role racial diversity plays in that process, it is important to consider the impact of earlier stages as well. Below I theorize what the likely impact of racial diversity should be in this process.

\section{Collective action, race, and repression}

That the organizing process has several distinct stages has implications for how diversity might affect the outcomes of organizing drives. Most fundamentally, a focus on interpersonal mechanisms within the work group is too narrow. Consider for example how the record of an organizing drive is generated. All representation elections in the NLRB's data were proceeded by successful card drives, yet it is in that earlier stage where much of the risk and drama of union organizing happens, and where most tales about racial division and animosity among groups of workers are set 
(Botsch 1980, Hill 1996, Milkman 2006). It can be argued, quite reasonably, that the success or failure to build trust across racial lines or the other interpersonal mechanisms that prior research has emphasized better explains the outcomes of card drives than the outcomes of elections. While mistrust can still derail collective action after the election petition is filed, the data here comprise those work groups that sufficiently overcame mistrust to file the petition. We should be less likely to see diversity derailing these cases, and we should be less willing to attribute it to intra-group dynamics if we do.

Instead, we might consider influences from outside the work group. Though the NLRA originally envisioned that unionization was a process of self-organization among workers and unions (Tomlins 1985), employers have taken increasing steps to influence the pre-election stages. Employers have for a generation been increasingly ruthless in their willingness to oppose union organizing drives, using both legal tactics like union-avoidance consultants and illegal "unfair labor practices" like firing and intimidating workers for union activity (Freeman \& Kleiner 1990, Cohen \& Hurd 1998, Bronfenbrenner 2009). If employers feel particularly threatened by collective action by diverse groups, or if they think that interventions against diverse groups are particularly likely to succeed, then we would see more aggressive employer resistance against efforts to organize more diverse work groups.

Given the long-supposed negative relationship between racial diversity and trust among workers, employers may think that strong interventions in such situations will be more effective. As Gamson (1990) argued in his classic study of the strategy of social movements, "[I]t is not the weakness of the user but the weakness of the target that accounts for violence" (p. 82). Violence is rare in contemporary labor organizing, ${ }^{2}$ but employers have access to several tactics that are formally illegal. The two most common types of "unfair labor practices," defined by section 8(a) of

\footnotetext{
${ }^{2}$ Though higher than in most other social movements - see Smith (2003).
} 
the Wagner Act, are unlawful intimidation and firing of employees for their union activity. Firing a worker who is visibly active in the union is a strong signal of employer willingness to fight an organizing attempt, but it is also risky insofar as there is some chance of being charged, investigated and possibly prosecuted for doing so. The same holds for intimidating workers in one-on-one meetings with management (Bronfenbrenner \& Juravich 1995, Cohen \& Hurd 1998), explicitly threatening to close an establishment if it becomes unionized (Bronfenbrenner 1996), and other techniques. A workforce divided among racial and ethnic lines is, all else equal, a workforce where such employer actions are more likely to exacerbate existing fear and doubt, and thus where employers are more likely to take such actions. ${ }^{3}$

Alongside this "weakness" explanation for why racial diversity might provoke stronger employer responses, social-movement researchers advance a "threat" explanation (Earl, Soule \& McCarthy 2003, Soule \& Davenport 2009). While authorities may not believe that challenges from move diverse groups are easier to defeat, they may feel more threatened by such challenges and therefore respond disproportionately to them. Thus for example protests with more black participants have tended to draw harsher police responses (Davenport, Soule \& Armstrong II 2011). Within the broader literature on union organizing, there are multiple accounts of how employers have reacted with alarm and often force to organizing attempts that bridged traditional racial divides (Jeffreys-Jones 1979, Botsch 1980, Griffith 1988, Cowie 1999). In their studies of various organizing campaigns, both Milkman (2006) and Cohen \& Hurd (1998) also argue that employers in industries with more non-white workers are less hesitant to break the law.

I cannot distinguish between weakness and threat mechanisms with these data,

\footnotetext{
${ }^{3}$ Gamson (1990) also found that violence or other forceful responses against social movements are more likely when the movement in question is a "target-displacement group," one that cannot achieve its goals without somehow reducing the power of another, established group. Because they almost necessarily infringe on managerial prerogatives (Chamberlain 1948), unions are an archetypical target-displacement group.
} 
but both types of theories make the same prediction: that employers will react more harshly to organizing drives among more diverse work groups. Since employer unfair labor practices have a much stronger impact on the probability of petition withdrawal than on election results (Ferguson 2008), more aggressive employer responses to more diverse work groups may help account for the higher failure rates of organizing campaigns among these groups.

\section{Data and variables}

\section{Data sources}

The primary data for this study come from three sources: the case records for unionrepresentation elections and the complaint records about unfair labor practices, which are both maintained by the NLRB; and the annual EEO-1 establishment surveys, which are recorded by the EEOC. Under the provisions of the National Labor Relations Act of 1935, the NLRB is tasked with overseeing the formation of new bargaining units and with investigating charges of unfair labor practices. The NLRB opens a representation case when a union, employer or individual files an election petition, as described above. The case is closed if the election petition is dismissed or withdrawn, or after the election is held (McGuiness \& Norris (1986) review the process in detail). The NLRB opens a complaint case when a union, employer or individual charges that another party has committed an unfair labor practice under the terms of the act. ${ }^{4}$ Like a representation case, the complaint case is closed when the original complaint is either withdrawn, dismissed, settled or judged by the board. NLRB data become public once cases are closed, and the corresponding records are available through

\footnotetext{
${ }^{4}$ I focus here on $8(\mathrm{a})$ violations, those committed by employers. The NLRA also defines $8(\mathrm{~b})$ violations, which are unfair labor practices by the union. Such charges account for less than 20 percent of all ULP charges filed each year, and are rarer still during organizing drives, where the union is not established. Fewer than 4 percent of the drives examined here had 8(b) charges, and controlling for such charges has no effect on the presented results.
} 
http://data.gov. NLRB records are available beginning in fiscal year 1999, when the agency adopted a new case-tracking database; thus I start my analysis in that year.

Under the Civil Rights Act (amended) of 1964, private employers with more than 100 employees must file annual EEO-1 reports with the EEOC. ${ }^{5}$ These reports include a matrix that details the race and sex of employees across nine broad occupational categories. These are the most detailed establishment-level data on workforce composition available (Robinson, Taylor, Tomaskovic-Devey, Zimmer \& Irvine Jr. 2005), and have been used in multiple studies in particular of women and minorities' progress into management (Kalev, Dobbin \& Kelly 2006, Cohen, Huffman \& Knauer 2009, Huffman, Cohen \& Pearlman 2010). Here I focus on the non-managerial workforce described in the reports. I obtained EEO-1 data from the EEOC through an Intergovernmental Personnel Act (IPA) agreement. Taken together, the NLRB and EEOC's data allows an analysis of diversity and collective action that is both fine-grained and representative, since they cover establishments across the United States.

To construct a linked dataset, I first matched the NLRB's representation cases with the EEO-1 surveys, based on establishment address. ${ }^{6}$ Of the 45,269 establishments where representation cases were opened over the period, 7,921 have a corresponding EEO-1 survey. Here it must be remembered that the EEOC only surveys large establishments. A non-match with the NLRB data is most likely due to the targeted establishment's being below the EEOC's employment threshhold, rather than a missing record. Indeed the 7,921 matched records cover 91 percent of the represen-

\footnotetext{
${ }^{5}$ Executive Order 11246 extends this annual reporting requirement to establishments of 50 or more employees, if those establishments have at least $\$ 50,000$ of federal contract work annually.

${ }^{6}$ I matched NLRB and EEOC data using the reclink package in Stata (Blasnik 2010), which allows for inexact matching of strings. To match the records, I first standardized address information (placing words in lower case, standardizing abbreviations and so on), then used reclink to calculate a score for each possible match based on the Levenshtein distance between the address strings. I counted as matches any candidates with a score of 0.9 or higher. See the reclink documentation for details.
} 
tation cases that propose bargaining units of more than 100 employees.

A potential concern when linking these data is how to identify the work group that is targeted by the union-organizing campaign, which may be a subset of the establishment workforce. The EEOC analyzes establishment workforces into nine occupational categories. The NLRB classifies cases into one of ten "bargaining unit types," and the two organizations' categories do not directly correspond. Both for example break out "Craft Workers" and "Professionals" from other job types, but their criteria for assigning specific establishments or work groups to those categories may differ. It is also not obvious how to map the NLRB's "Departmental" category for example onto the EEOC categories. It is nonetheless important to try to specify the composition of the targeted work groups as exactly as possible, because the racial demography of work groups can vary considerably by job types within an establishment (Tomaskovic-Devey et al. 2006). Using establishment-wide measures of workforce composition can introduce considerable measurement error.

Specifying the subset of the workforce on the EEO-1 survey to treat as the targeted work group for calculating diversity measures is therefore subjective. I detail my assignment procedure in appendix A. To get a sense of whether my results are sensitive to that procedure, I reproduced my analyses using diversity metrics calculated from the full establishment population listed on the EEO-1 survey. My rationale for doing so is that using the full establishment population for comparison gives a sense of whether and how sensitive my results are to my choice of sub-groups to match with different NLRB unit types. Those models are available in appendix A; the substantive pattern of results is not changed.

To determine how many of the organizing drives were associated with ULP charges, I matched these 7,921 records with the NLRB's complaint cases, following a procedure like that employed in Ferguson (2008). The representation-case record has fields where NLRB staff can note corresponding ULP charges; similarly the complaint-case 
record has fields for related representation cases. Based on such direct documentary evidence, I find ULP charges associated with 1,667 of the organizing drives. This 21-percent rate of exposure closely matches the rate calculated by Ferguson (2008) for all organizing drives between 1999 and 2004. NLRB staff are not required to fill in all such documentary fields, so this rate is almost certainly an understatement of the actual rate of ULP charges. I therefore also linked the representation and complaint records using establishment address, as with the EEO-1 surveys. This procedure yields another 1,589 matches, for a 41-percent rate of exposure. While a two-in-five rate of charges of illegal activity may seem disconcertingly high, it is not out of line with similar analyses done by Bronfenbrenner (2009). The 21- and 41-percent rates may be thought of as upper and lower bounds on the actual rate of illegal opposition to union activity during the last decade. Using the more conservative and liberal match criteria yield substantively similar results. Below I present results using the conservative match criterion; alternative models are available on request.

Data for control variables come from several sources. State- and industry-level information on union density come from the cross-tabulations of the Current Population Survey compiled by Hirsch \& Macpherson (2004). The right-to-work status of states is reported by the National Right To Work Foundation. The political composition of the National Labor Relations Board is compiled from the NLRB's website.

\section{Variables}

The dependent variables in the analysis below are whether an election was held in a proposed bargaining unit and whether the election was won. Both are binary variables. I code an election as held if the NLRB's case record includes information on the conduct of an election. I code the outcome as a withdrawal if the case's closing method is specified as a withdrawal by the petition filer. The two outcomes are exclusive but not exhaustive, because a small portion (2.8 percent) of the election 
petitions are dismissed or put on some sort of administrative abeyance. I exlude such cases in the analyses. I code an election as won based on the NLRB's published vote count, as well as the case-closing method's being specified as "Certification of Representative" rather than "Certification of Results," the board's term for a loss. There are a few cases that end in administrative limbo and are excluded.

The main independent variable of interest is an index of the racial diversity of the workforce in the proposed bargaining unit. The EEO-1 survey includes separate information for seven racial or ethnic classes: White, Black or African American, Hispanic or Latino, ${ }^{7}$ Native Hawaiian or other Pacific Islander, Asian, American Indian or Alaska Native, and Two or More Races. In preliminary analyses I found no substantial differences when breaking out the last four classes, which account for small or zero shares in most establishments. (In 88 percent of all cases, all of the nonblack, non-latino workers are white.) I thus construct a Simpson Index of diversity, $D=\sum_{1}^{4} p_{i}^{2}$, where $p_{i}$ are the shares of white, black, latino, and "other" workers. The Simpson index decreases as diversity increases; I subtract the index from unity to aid in interpreting the model coefficients.

To give an idea of how diversity changes at different stages of the organizing process, table 1 shows the number of organizing drives that pass through each observed stage. Table 1 compares the cases where the workforce is homogeneous (i.e., $D=0$ ) to those where it is not. As the cumulative survival rate suggests, homogeneous units were more likely to make it through an entire organizing drive, which would seem to support the idea that diversity hurts collective action. However, this higher survival rate is not because homogeneous units were more likely to vote for the union. Unions won the election in only 52.8 percent of the homogeneous work groups, compared to

\footnotetext{
${ }^{7}$ There are well-documented measurement problems with treating black, white and particularly latino as exclusive categories (Snipp 2003, Hitlin, Brown \& Elder Jr. 2007). Model results for latinos are often attenuated, thanks to the measurement error inherent in the classification. When I run specific analyses for latinos, I find such a pattern: coefficients for Latino workers variously resemble those for black and white workers, with larger standard errors.
} 
59.6 percent of the heterogeneous ones. Rather, diverse work groups exit the process at higher rates before elections are held: while unions give up and withdraw their election petitions 26.8 percent of the time when the work group does not have racial diversity, they do so 39.8 percent of the time when the work group is diverse. This difference in withdrawal rates is large enough to swamp the difference in election results. I explore the possible causes of these different survival rates below.

[Table 1 about here.]

The coding of whether an unfair labor practice charge occurred is described above. Construction of the other controls are straightforward. The size of the work group is an obvious confound, both because diversity usually increases as size increases and because unit size has a well-documented negative relationship with election victory (Farber 2001). When modeling whether an election is held, I use the logged proposed size of the bargaining unit on the election petition. When modeling whether an election is won, I use the logged number of eligible voters. These numbers are correlated but rarely identical, due to the NLRB's rulings on eligible workers. So-called right-to-work laws prevent the unions at a workplace from requiring employees to join and pay dues while giving those employees the benefits of the contract; as such, they are recognized as weakening unions' ability to organize (Elliott \& Huffman 1984). Because such laws have historically been most common in the states of the former Confederacy, focusing on the racial composition of the workforce may spuriously pick up effects associated with the broader race relations of the local economy. I record the presence of a right-to-work law as a binary variable. The private-sector union density of the state is also included, to control for other unobserved historical or political factors that might make organizing easier or harder. Unobserved events that lower the likelihood of an organizing drive's success, such as strife among groups of workers or legal resistance by the employer, will also tend to drag out the period between petition and election. Unions also typically file election petitions when they think 
conditions are best for a vote, so unexpected delays often can cause discouragement or disinterest by the employees (Miller \& Leaming 1962, Flanagan 1989). Accordingly, I follow the practice in prior studies of organizing drives and include the linear and squared effects of delay, measured as the number of days between filing a petition and either withdrawal or the holding of the election. Finally, I present most models with successive inclusion of fixed effects for the establishment's two-digit industry, the union involved in the drive and the region of the country (northeast, midwest, south, plains states, mountain states or west coast). ${ }^{8}$ Table 2 presents descriptive statistics for the variables used in each stage of the models.

[Table 2 about here.]

\section{Models and results}

\section{Effects of Diversity}

When considering the effects of diversity as such, the null hypothesis should be that any difference in group outcomes is due to differing sub-group characteristics, and that the combination of sub-groups has no additional effect. In this context, this means controlling for the different propensities of racial sub-groups to go through with elections and to vote for unions. Black workers are more likely to be unionized and more likely to vote for unions in elections (Freeman \& Medoff 1984, Isaac, McDonald \& Lukasik 2006, Rosenfeld \& Kleykamp 2012). How the voting patterns of latinos and other non-white workers differ from whites is less clear from theory, and there is mixed evidence about whether they favor unions at higher rates than whites (Rosenfeld \& Kleykamp 2009). Accordingly, any observed effects of diversity - a higher likelihood

\footnotetext{
${ }^{8}$ State- or even MSA-level fixed effects would be preferable to region effects, but including those fifty or more variables in the models often causes them to fail to converge. I have instead created broad regions that are internally consistent with regard to their history of trade unionism. Models using state-level random effects produce substantively similar results.
} 
to vote for unions, for example - could be due simply to the presence of more minority workers in the unit.

Table 3 summarizes a simple test of this null hypothesis, showing the relationship between diversity and the various outcomes while controlling for specific group memberships. It presents logit models of holding and winning elections, first as a function of diversity and then as a function of diversity and the unit's share of various minority workers. Considering models 1 and 5, more diverse work groups are less likely to hold elections but more likely to win them. Model 6 demonstrates that the effect of diversity on election success can be accounted for by the presence of more black workers. Model 2, by contrast, shows that while drives with more black workers are more likely to go through with elections, that effect partially masks a strong reduction in the likelihood of holding a vote that is associated with diversity. The .653 coefficient on share black in model 2 implies that a completely black workforce is 15.8 percent more likely to hold an election than a homogeneous, non-black workforce. ${ }^{9}$ Given a mean election rate of 62 percent, this translates into a $(.62 \times 1.158)-.62=9.79$ percentage-point difference. By contrast, the diversity coefficient in model 2 shows that a workforce that is evenly divided between whites, Latinos, and others is 17.6 percent less likely to hold an election than a homogeneous workforce is (by the same math, a 10.9 percentage-point difference).

[Table 3 about here.]

Table 3 demonstrates three things. First, in line with table 1, diversity seems to be positively correlated with election success, in contrast with much prior theorizing. Second there is little evidence that diversity as such drives union voting. The positive effect suggested in table 1 is largely reducible to the different propensities of different racial groups, particularly blacks, to favor unionizing. Second, diversity is associated with higher rates of withdrawal before elections, and that higher rate of withdrawal

\footnotetext{
${ }^{9}$ This is the marginal effect calculated from the logit coefficient, using Stata's mfx command.
} 
swamps the difference in voting behavior. But table 3 has two weaknesses. First, it does not include controls for confounding variables. Second and equally seriously, it treats the two outcomes as independent events. Yet precisely because unions can withdraw their election petitions, and indeed are likely to if they think they are going to lose, we cannot assume independence. Rather, the withdrawal decision is endogenous to the election outcome.

To see why endogeneity is a potential problem, presume that organizing drives among more diverse work groups are more likely to collapse, for reasons unrelated to diversity per se. For example, employment diversity varies by industry, as do withdrawal rates. The correlated likelihood of withdrawal biases the sample of elections, in that the "real" likelihood of winning the election is higher than expected because the predicted losers have selected out. The two outcomes can be thought of as a selection model (Heckman 1979). If $y_{i}$ is the observed election outcome for organizing drive $i$ and $d_{i}$ is the diversity of the work group involved in the organizing drive, then we can presume there exists a latent relationship between the two variables, $y_{i}^{*}=\delta d_{i}+x_{i} \beta+u_{1 i}$, and that we observe $y_{i}$ only if $y_{i}^{*}>0$. Whether the election is held, $h_{i}$, is the result of a separate selection equation: $h_{i}=\nu d_{i}+z_{i} \gamma+u_{2 i}$. In this set-up, $u_{1}$ and $u_{2}$ both follow standard normal distributions and $\operatorname{corr}\left(u_{1}, u_{2}\right)=\rho$. Because the $u_{1}$ and $u_{2}$ are correlated, the coefficient $\delta$ in the first equation suffers from omitted variable bias.

I account for this bias by estimating bivariate probit models, which directly model the correlation between the error terms in the two stages of the organizing process. To satisfy the exclusion restriction for the first stage of these models (Winship \& Mare 1992), I rely differences between the proposed and voting unit size, discussed above; the overall case delay as compared to the delay before elections in non-censored cases (Miller \& Leaming 1962); and shifts in the opportunity structure for appealing to the National Labor Relations Board, which I operationalize based on the changes during 
the time period in the presidential administration and the political affiliation of the majority of board members. The administration and Board-composition variables are particularly useful in this case because, while organizers typically pay close attention to the relative sympathy of regulators when deciding whether to go to election or withdraw, we have little reason to assume that these political variables affect workers' votes, except indirectly via the decision to hold an election.

Table 4 shows the estimates from such two-stage model. The sign on the coefficient of diversity for holding an election in models 9 through 12 is the same as in table 3 , though the magnitude of the effect is considerably smaller. This is consistent with endogeneity between the two outcomes, as suggested by the significant correlation between stages' error terms $(\rho=.971, p<.01)$. Diversity has no apparent relationship with winning an election, once other controls are included.

[Table 4 about here.]

Models 10 through 12 introduce controls for different racial sub-groups. Even when controlling for other factors, larger shares of black workers are associated with greater probabilities both of holding and winning elections. The negative effect of diversity on holding elections persists in these models.

The other controls in table 4 move in expected directions. Unit size has the typically seen negative relationship with winning elections (Olson 1965, Farber 2001), and also the positive relationship with holding elections (Ferguson 2008). A ULP charge is associated with a higher probability of withdrawal, though among elections the drives that had ULP charges are more likely to succeed. This again is consistent with sample selection, as is the estimated effects of right-to-work laws: more likely to result in withdrawal, no effect upon election. Delay's effect moves in the expected direction in each stage, increasing the likelihood of an election for about 60 days before starting to reduce it, ${ }^{10}$ and decreasing the likelihood that the election succeeds.

\footnotetext{
${ }^{10}$ Delay's effect is necessarily non-linear when modeling whether an election is held, because there
} 
Unions were more likely to go through with elections rather than withdraw when there was a Democrat in the White House and when the National Labor Relations Board had a Democratic majority.

State union density has a small but significant negative relationship with holding elections. This probably reflects differences in the opportunity structures that unions face. All else equal, a union is more likely to go ahead with an organizing drive in a state like New York or Pennsylvania than in a state like North Carolina or Texas. Such lesser selectivity means that the union is more likely both to file and to withdraw a "weak" election petition in the more labor-friendly states. In more hostile environments, where unions are more selective about starting a drive, that weaker petition would not be filed. Consistent with this idea, any effect of state union density disappears by election.

\section{Why might diversity increase withdrawals?}

The results so far show that diversity is associated with a greater likelihood of withdrawal of election petitions but not with a greater likelihood of failed election votes. There remains the question why diversity has this effect on withdrawal rates. I have theorized that more diverse units face stiffer employer resistance. To test this idea, I fit logistic models where the outcome is the presence of a ULP charge and the independent variable of interest is my measure of diversity. Table 5 presents those models. Model 13 shows that more diverse units do have ULP charges associated with them. ${ }^{11}$ This effect persists in models 14 through 16, which include the shares of black, latino and other workers. These groups face higher, lower and comparable rates of ULP charges, respectively, than white workers. Model 17 includes several is a minimum period during which the NLRB processes the election petition and signs off on the unit as proposed.

${ }^{11}$ In other analyses available on request, I fit models with variables for each decile of diversity, rather than constraining a linear effect. These models suggest that most of the effect of diversity shows up between the first decile and the rest, that is, between homogeneous units and diverse ones. 
other likely predictors of ULP charges, in particular fixed effects for each organizing drive's state, two-digit industry and union involved. Here too diversity is associated with a higher likelihood of ULP charges.

[Table 5 about here.]

Model 17 shows that diversity's relationship to ULP charges is robust to multiple fixed effects. The obvious question is what including such fixed effects would do to diversity's relationship to holding and winning elections. Table 6 reproduces the models from table 4 while adding in similar fixed effects. ${ }^{12}$ Models 18 and 19 show that diversity's negative relationship with holding elections cannot be explained by unobserved differences between the unions or industries involved. Model 20 through shows that the relationship can be mediated by differences between geographic regions. ${ }^{13}$ This mediation suggests that both diversity and withdrawal behavior vary systematically by region.

[Table 6 about here.]

What might produce such covariance? In general, the regions of the United States that are more anti-labor tend to have more homogeneous workforces. If unions pick their battles more carefully in more anti-labor regions (Wessels 1981), then withdrawal rates will also be lower in anti-labor regions. In other words, if unions in more diverse, more pro-labor areas are inclined to go ahead and file election petitions in marginal organizing campaigns, they will induce some spurious correlation between diversity and petition withdrawal.

The bivariate-probit models fit here offer a way to test this possibility, albeit indirectly. Recall that the argument for fitting such models turns on potential endogeneity between the two stages. That endogeneity would result from unions withdrawing

\footnotetext{
${ }^{12}$ Adding in racial sub-group shares to the models in table 6 does not change the substantive results.

${ }^{13}$ The states in each region are listed in table 7.
} 
when they expect to lose elections. The more often that unions withdraw in the face of likely losses, the larger the correlation between the errors in the two stages of the model - the $\rho$ parameter - will be. This type of endogeneity maps well onto the differences between pro- and anti-labor regions just discussed. If unions are more cautious about filing petitions in anti-labor regions, they will have fewer occasions to withdraw in anticipation of a loss than they will in pro-labor regions. Thus the $\rho$ parameter will be smaller in less labor-friendly regions like the south and the great plains.

I fit model 9 from table 4 separately for six regions. Table 7 presents the $\rho$ paramater for each. In the comparatively union-friendly regions of the northeast, midwest and pacific west, $\rho$ is large and statistically significant. By contrast, $\rho$ is marginally significant in the mountain west and non-significant (and much smaller) in the south and on the plains. Taken together, the results in tables 6 and 7 suggest that differences in diversity and in withdrawal behavior between regions help explain some of diversity's effect on withdrawals.

[Table 7 about here.]

We can thus observe two channels through which diversity can be associated with higher withdrawal rates. One stems from differences in union behavior across different regions, and is arguably spurious. The other stems from different employer responses to more diverse work groups. This second channel cannot be attributed to spurious compositional differences, as the robustness of the coefficient on diversity to fixed effects in table 5 (and of the coefficient on ULP charges in table 6) demonstrates. The crucial association between workforce diversity and lower rates of union formation, therefore, operates through the increased likelihood of employer ULPs in the stage before election, and the higher rate of petition withdrawals in the wake of ULPs. The greater propensity of some minority groups to vote for unions in elections is not enough to balance this effect. 


\section{Discussion}

Union formation is a contentious activity, where we must consider actions taken to repress collective action as well as mobilization in favor of it. It requires trust and solidarity among the mobilized. Work groups vary in their diversity, which gives researchers an unusual opportunity to see how ascriptive differences affect the outcomes of such mobilization attempts. Because there is a deep historical record of the difficulties in engaging in collective action across racial lines in the United States, we have a strong prior prediction about what racial and ethnic diversity's effects should be in these cases.

This study has shown that, in line with such beliefs, bargaining units that are formed are less diverse than bargaining units that try to form. Yet I have also shown that, when given the chance to express their preferences at election, more diverse groups opt for unions. As befits a process involving other potentially influential actors (King, Cornwall \& Dahlin 2005, Ferguson 2008), we gain more understanding of the relationship between racial diversity and union formation if we widen our focus to include other stages of that process and the actors beyond the workers themselves. While workers' cohesion matters, so too does the union's skill at choosing where to file petitions and, most importantly, the employer's willingness to respond beyond what the law allows. Perhaps the most surprising finding here is that employers are charged with intimidating and firing people more often in more racially diverse work groups. One contribution of this study then is to propose a different mechanism for why racial diversity makes it harder for workers to unionize than is often proposed.

Much of the prior writing about the tribulations of cross-racial organizing concern the early, informal stages of an organizing drive, the card drive in particular. Such focus on the very early stages is often justified. Before the 1935 Wagner Act, such "informal" organizing was essentially the only type available. And if the researcher's interest lies in how unions build trust with workers from different racial 
or ethnic backgrounds, such early-stage work is critical. Yet most union organizing efforts are directed toward and happen through the formal, bureaucratic process that was stipulated by the Wagner Act. Labor organizing historically resembled other types of social-movement mobilization, and still does in the organizing drive's early stages, but the Act created a mechanism to channel such mobilization into a statesupervised system where both the outcomes and the behavior of the parties could be monitored, adjudicated, certified and recorded. Union formation is thus a hybrid organizational process, one that shares features both with less formal social mobilizations like the anti-war or environmental movements and with more formal organizational routines like passing laws (Soule \& King 2006) or hiring employees (Fernandez \& Weinberg 1997). Stratification research has shown that increasing the bureaucratization of employment relations has not eliminated racial or ethnic bias but has channeled its expression, often in unanticipated ways (Dobbin 2009). Given the interest in applying theories from social movements to formal organizations and vice versa (Davis, McAdam, Scott \& Zald 2005, Davis, Morrill, Rao \& Soule 2008, Soule 2009), another contribution of this paper is its exploration of how the formalization of union organizing drives channels the expression of such bias.

Results like these, where a group-level effect such as diversity is correlated with larger groups that also vary in their demographic composition, pose complicated causal questions. Do some employers become more willing to violate the law as their workforce becomes peopled by disadvantaged social groups, or do worsening employment conditions cause more advantaged social groups to seek opportunities elsewhere, leaving positions to be filled by the less advantaged? Little definitive work on distinguishing between such mechanisms has been done. The limits of the available data force me to bracket the question in this study. I demonstrate here that much of the variance in group outcomes can be accounted for by differences in racial composition across regions and employers' reactions, but the causes of those 
relationships should be the focus of future research.

Two potential concerns about these findings are worth addressing. The first involves how organizing drives enter the data set. All of the units considered here went through a successful card drive. It could be argued that the sort of intra-group racial and ethnic conflict that older union research emphasized best explain the outcomes of card drives. I do not argue otherwise. Rather, this study demonstrates that, even among diverse groups that were cohesive enough to succeed in a card drive, diversity has further negative effects associated with it that are at best only indirectly related to interpersonal interactions in the work group. Thus I have argued that the filtering provided by the card drive is helpful to this analysis. If there were not such a difficult hurdle that had to be cleared before coming under observation, then it would be much easier to chalk up diverse establishments' higher rates of petition withdrawal to lack of enthusiasm or commitment. The pre-screening makes this less plausible, as does the systematic covariation of diversity and withdrawal across different states.

The second concern is that the NLRB records charges of unfair labor practices against employers, not the practices themselves. It is possible that union campaigns in more diverse work groups fail because of the social distance among employees, but that to save face the union charges the employer with ULP activity when it withdraws. This would exaggerate both the negative effects of diversity and the negative effects of the ULP charge. Empirical risks like these motivate my use of the two-stage selection model shown in table 4. In models that do not control for endogeneity between holding and winning elections (available on request), the relevant effects on withdrawal appear nearly twice as large. In other words, unions probably do file ULP charges against employers strategically, often to save face; but controlling for that source of bias does not wipe out the effects seen here. ${ }^{14}$

Finally, one part of the empirical findings demands further study. Why do em-

\footnotetext{
${ }^{14}$ As might be expected, the magnitude of that bias is smaller when one uses the liberal matching criterion for ULP charges described above, due to likely measurement error.
} 
ployers intimidate and fire workers more often when work groups are more diverse? As with the withdrawal rate, this is not simply the result of different employer reactions to workers of different races. Table 5 shows that employers are more likely to be charged with ULPs when more black workers are involved in the organizing drive ${ }^{15}$ but that diversity carries an additional risk even when controlling for this. I have argued that stronger employer reactions to the mobilization of diverse work groups is in line with other research on the repression of collective action (Earl, Soule \& McCarthy 2003, Davenport, Soule \& Armstrong II 2011), and indeed this trend may just reflect the divide-and-rule tactics that American employers have long used in fighting union organizing campaigns (Lichtenstein 2002, Clawson 2003, Fantasia \& Voss 2004). The obvious next step for future research in this vein will be to flesh out the characteristics of the employers involved, to understand what if any features those who commit unfair labor practices share beyond the demographics of their workforces. Such research will require more detailed employer data than was available for this study, but the potential contribution toward our understanding of the dynamics both of unions' membership diversification and the response of private actors to social mobilization could be considerable.

\footnotetext{
${ }^{15} \mathrm{ULP}$ charges are less likely as the share of latino workers increases. This may reflect the interaction of immigration status and the propensity to seek legal recourse among many working-class latinos: while the NLRA protects the union rights of workers regardless of immigration status, non-citizens have other reasons to be wary of making their presence known to law enforcement or formally challenging their employers. Unfortunately, neither the NLRB nor the EEOC record the immigration-status data necessarily to test this directly.
} 


\section{A Matching NLRB bargaining-unit types to EEO- 1 job categories}

As discussed in the text, union organizing drives often target a subset of the workforce in a given establishment. Thus when calculating metrics of diversity for the work group targeted by an organizing drive, we would like to know which establishment employees are in the relevant work group. Because the NLRB and the EEOC classify workers into coarse categories that do not perfectly correspond to one another, exact matching is impossible. I therefore chose which job categories on the EEO-1 establishment survey to use when calculating the diversity measures for each case, based on the bargaining unit type into which the NLRB classified the case. To develop these correspondences, I relied on the EEOC's EEO-1 Job Classification Guide, which can be found online at www. eeoc.gov/employers/eeo1survey/upload/jobclassguide.pdf. This guide maps the 2000 Census Job Codes and Titles into the EEO-1 survey's ten job categories. By referencing the descriptions of targeted workers in the NLRB case files and the bargaining unit type assigned to each case file, I built a mapping between NLRB bargaining unit types and EEO-1 job categories. That mapping is as follows:

\begin{tabular}{r|l|l}
$\%$ & NLRB type & EEO-1 categories used \\
1.76 & Clerical & Sales Workers; Office \& Clerical; Service Workers \\
6.03 & Craft & Technicians; Craft Workers (Skilled) \\
14.21 & Departmental & Craft; Operatives (Semi-Skilled); Laborers (Unskilled); Service \\
2.99 & Guard & Service \\
1.48 & Health & Technicians; Off \& Cler; Operatives; Laborers; Service \\
11.79 & Industrial & Operatives; Laborers; Service \\
2.79 & Prof/Cler & Professionals; Technicians; Off \& Cler \\
1.24 & Professional & Professionals; Technicians \\
4.23 & Truck Drivers & Operatives; Laborers \\
53.48 & Other & All non-managerial categories
\end{tabular}

The left-most column above shows the percentage of all 7,921 cases with each bargaining-unit type. Note that more than half of all NLRB cases list "Other" as 
the type. In these cases, I calculated the diversity metrics using the establishment's entire non-managerial workforce. It is worth underlining this point: more than half of the cases used in the main analyses cannot be affected by this mapping.

As a robustness check on my assignment procedure, I re-calculated diversity metrics as though every case was classified as "Other," using the full establishment workforce. The rationale behind this alternate calculation is that using the full establishment for all cases gives a sense for what results would look like had I made no substantive decisions about how to define the work groups, albeit at the cost of substantial measurement error.

Tables 8 and 9 reproduce the analyses from tables 3 and 4 in the main text. Most of the patterns of results from the main analyses remain unchanged in these robustness checks. The main exception inheres in the models that include "Share other." Model A4 in table 8 does not converge when using this coarser measure of Asian and Native-American shares. Perhaps for similar reasons, model A12 of table 9 gives divergent results from model 12 of table 4.

[Table 8 about here.]

[Table 9 about here.]

It is also worth noting that, while "Share black" moderates the effects of diversity on winning elections in model 6 of table 3, it does not do so in model A6 of table 8. This too may have to do with the coarser measure of the share of black workers in the specific bargaining unit, as well as the diversity of the unit. The mediation is reproduced in model A10 of table 9 . 


\section{References}

Bacharach, Samuel B. \& Peter A. Bamberger. 2004. "Diversity and the Union: The Effect of Demographic Dissimilarity on Members' Union Attachment." Group and Organization Management $29(3): 385-418$.

Barling, J., C. Fullagar \& K. Kelloway. 1992. The Union and Its Members: A Psychological Approach. New York: Oxford University Press.

Blasnik, Michael. 2010. "RECLINK: Stata Module to Probabilistically Match Records.". URL: http://EconPapers.repec.org/RePEc:boc:bocode:s456876

Botsch, Robert E. 1980. We Shall Not Overcome: Populism and Southern Blue-Collar Workers. Chapel Hill, NC: University of North Carolina Press.

Bronfenbrenner, Kate. 1996. Final Report: The Effects of Plant Closing or Threat of Plant Closing on the Right of Workers to Organize. Technical report North American Commission for Labor Cooperation.

Bronfenbrenner, Kate. 2009. No Holds Barred: The Intensification of Employer Opposition to Organizing. Technical report Economic Policy Institute Washington, DC: . EPI Briefing Paper 235 .

Bronfenbrenner, Kate \& Robert Hickey. 2004. Changing to Organize: A National Assessment of Union Strategies. in Milkman \& Voss (2004).

Bronfenbrenner, Kate \& Tom Juravich. 1995. The Impact of Employer Opposition on Union Certification Win Rates: A Private/Public Sector Comparison. Technical Report 113 Economic Policy Institute.

Brudney, James J. 2005. Contractual Approaches to Labor Organizing: Supplanting the Election Paradigm? In Proceedings of the 57th Annual Meeting. Labor and Employment Relations Association pp. 106-113.

Brueggemann, John \& Cliff Brown. 2003. "The Decline of Industrial Unionism in the Meatpacking Industry: Event-Structure Analyses of Labor Unrest, 1946-1987." Work and Occupations 30(3):327-360.

Burstein, Paul \& April Linton. 2002. "The Impact of Political Parties, Interest Groups and SocialMovement Organizations on Public Policy: Some Recent Evidence and Theoretical Concerns." Social Forces 81(2):380-408.

Burstein, Paul, Rachel L. Einwohner \& Jocelyn A. Hollander. 1995. The Success of Political Movements: A Bargaining Perspective. In The Politics of Social Protest, ed. J. Craig Jenkins \& Bert Klandermans. Minneapolis: University of Minnesota Press pp. 275-295.

Chamberlain, Neil W. 1948. The Union Challenge to Management Control. New York: Harper.

Clawson, Dan. 2003. The Next Upsurge: Labor and the New Social Movements. Ithaca, NY: Cornell University Press.

Cohen, L. \& Richard Hurd. 1998. Fear, conflict and union organizing. In Organizing to Win: New Research on Union Strategies, ed. Kate Bronfenbrenner, Sheldon Friedman, Richard Hurd, R. Oswald \& R. Seeber. Ithaca, NY: ILR Press pp. 181-196.

Cohen, Lizabeth. 1990. Making a New Deal: Industrial Workers in Chicago, 1919-1939. New York: Cambridge University Press.

Cohen, Philip N., Matt L. Huffman \& Stefanie Knauer. 2009. "Stalled Progress? Gender Segregation and Wage Inequality Among Managers, 1980-2000." Work and Occupations 36(4):318-342.

Cowie, Jefferson R. 1999. Capital Moves: RCA's Seventy-Year Quest for Cheap Labor. Ithaca, NY: ILR Press. 
Davenport, Christian, Sarah A. Soule \& David A. Armstrong II. 2011. "Protesting While Black? The Differential Policing of American Activism, 1960 to 1990." American Sociological Review 76(1):152-178.

Davis, Gerald F., Calvin Morrill, Hayagreeva Rao \& Sarah A. Soule. 2008. "Introduction: Social Movements in Organizations and Markets." Administrative Science Quarterly 53:389-394.

Davis, Gerald F., Doug McAdam, W. Richard Scott \& Mayer N. Zald, eds. 2005. Social Movements and Organization Theory. Cambridge Studies in Contentious Politics Cambridge: Cambridge University Press.

DeFreitas, Gregory. 1993. "Unionization Among Racial and Ethnic Minorities." Industrial and Labor Relations Review 46(2):284-301.

Dobbin, Frank. 2009. Inventing Equal Opportunity. Princeton, NJ: Princeton University Press.

Dunlop, John T. 1958. Industrial Relations Systems. New York: Holt.

Earl, Jennifer, Sarah A. Soule \& John D. McCarthy. 2003. "Protest under Fire? Explaining the Policing of Protest." American Sociological Review 68:581-606.

Elliott, Ralph D. \& James R. Huffman. 1984. "The Impact of Right-To-Work Laws on Employer Unfair Labor Practice Charges." Journal of Labor Research 5(2):165-176.

Fantasia, Rick \& Kim Voss. 2004. Hard Work: Remaking the American Labor Movement. Berkeley, CA: University of California Press.

Farber, Henry S. 2001. "Union Success in Representation Elections: Why Does Unit Size Matter?" Industrial and Labor Relations Review 54(2):329-348.

Ferguson, John-Paul. 2008. "The Eyes of the Needles: A Sequential Model of Union Organizing Drives, 1999-2004." Industrial and Labor Relations Review 62(1):3-21.

Fernandez, Roberto M. \& Nancy Weinberg. 1997. "Sifting and Sorting: Personal Contacts and Hiring in a Retail Bank." American Sociological Review 62(6):883-902.

Flanagan, Robert J. 1989. "Compliance and Enforcement Decisions under the National Labor Relations Act." Journal of Labor Economics 7(3):257-280.

Fletcher Jr., Bill \& Richard W. Hurd. 2000. "Is Organizing Enough? Race, Gender, and Union Culture." New Labor Forum 6:58-67.

Freeman, Richard B. \& Joel Rogers. 1999. What Workers Want. Ithaca, NY: ILR Press.

Freeman, Richard B. \& Morris M. Kleiner. 1990. "Employer Behavior in the Face of Union Organizing Drives." Industrial and Labor Relations Review 43(4):351-365.

Freeman, Richard \& James Medoff. 1984. What Do Unions Do? New York: Basic Books.

Gamson, William A. 1990. The Strategy of Social Protest. 2nd ed. Homewood, IL: Dorsey Press.

Griffith, Barbara S. 1988. The Crisis of American Labor: Operation Dixie and the Defeat of the CIO. Philadelphia: Temple University Press.

Halpern, Rick. 1997. Down on the Killing Floor: Black and White Workers in Chicago's Packinghouses, 1904-54. Urbana, IL: University of Illinois Press.

Heckman, James. 1979. "Sample Selection Bias as a Specification Error." Econometrica 47:153-161.

Heneman, III, Herbert G. \& Marcus H. Sandver. 1983. "Predicting the Outcome of Union Certification Elections: A Review of the Literature." Industrial and Labor Relations Review 36(4):537559 .

Hill, Herbert. 1996. "The Problem of Race in American Labor History." Reviews in American History 24(2):189-208. 
Hirsch, Barry T. \& David A. Macpherson. 2004. "Union Membership and Coverage Database from the Current Population Survey." Available online at http://unionstats.com.

Hitlin, Steven, J. Scott Brown \& Glen H. Elder Jr. 2007. "Measuring Latinos: Racial vs. Ethnic Classification and Self-Understandings." Social Forces 86:587-611.

Huffman, Matt L., Philip N. Cohen \& Jessica Pearlman. 2010. "Engendering Change: Organizational Dynamics and Workplace Gender Desegregation, 1975-2005." Administrative Science Quarterly $55: 255-277$.

Isaac, Larry, Steve McDonald \& Greg Lukasik. 2006. "Takin' it from the Streets: How the Sixties Mass Movement Revitalized Unionization." American Journal of Sociology 112(1):46-96.

Iverson, R. D. \& S. Kuruvilla. 1995. "Antecedents of Union Loyalty: The Influence of Individual Dispositions and Organizational Context." Journal of Organizational Behavior 16:557-582.

Jeffreys-Jones, Rhodri. 1979. "Theories of American Labour Violence." Journal of American Studies 13:245-264.

Kalev, Alexandra, Frank Dobbin \& Erin Kelly. 2006. "Best Practice or Best Guesses? Diversity Management and the Remediation of Inequality." American Sociological Review 71:589-617.

King, Brayden G., Marie Cornwall \& Eric C. Dahlin. 2005. "Winning Woman Suffrage One Step at a Time: Social Movements and the Logic of the Legislative Process." Social Forces 83:1211-1234.

Kochan, Thomas, Harry Katz \& Robert McKersie. 1986. The Transformation of American Industrial Relations. Ithaca, NY: ILR Press.

Lichtenstein, Nelson. 1995. Walter Reuther: The Most Dangerous Man in Detroit. Urbana and Chicago, IL: University of Illinois Press.

Lichtenstein, Nelson. 2002. State of the Union: A Century of American Labor. Princeton, NJ: Princeton University Press.

Lüthje, Boy \& Christoph Scherrer. 2001. "Race, Multiculturalism, and Labour Organizing in the United States: Lessons for Europe." Capital \&3 Class 25(1):141-171.

Martin, Andrew W. 2008a. "The Institutional Logic of Union Organizing and the Effectiveness of Social Movement Repertoires." American Journal of Sociology 113(4):1067-1103.

Martin, Andrew W. 2008b. "Resources for Success: Social Movements, Strategic Resource Allocation, and Union Organizing Outcomes." Social Problems 55(4):501-524.

McGuiness, Kenneth C. \& Jeffrey A. Norris. 1986. How to Take a Case Before the NLRB. fifth ed. Washington: Bureau of National Affairs, Inc.

Milkman, Ruth. 1987. Gender at Work: The Dynamics of Job Segregation by Sex during World War II. Champaign, IL: University of Illinois Press.

Milkman, Ruth. 1993. Union Responses to Workforce Feminization in the U.S. In The Challenge of Restructuring: North American Labor Movements Respond, ed. J. Jenson \& R. Mahon. Philadelphia: Temple University Press.

Milkman, Ruth. 2006. L.A. Story: Immigrant Workers and the Future of the U.S. Labor Movement. New York: Russell Sage Foundation.

Milkman, Ruth \& Kim Voss, eds. 2004. Rebuilding Labor: Organizing and Organizers in the New Union Movement. Ithaca, NY: ILR Press.

Miller, Richard U. \& George F. Leaming. 1962. "The Extent and Significance of Administrative Delays in the Processing of Union Representation Cases in Arizona." Arizona Review of Business and Public Administration 2(9):1-11.

Nelson, Bruce. 2001. Divided We Stand: American Workers and the Struggle for Black Equality. Princeton: Princeton University Press. 
Nissen, Bruce. 2002. "The Role of Labor Education in Transforming a Union Toward Organizing Immigrants: A Case Study." Labor Studies Journal 27(1):109-127.

Olson, Mancur. 1965. The Logic of Collective Action: Public Goods and the Theory of Groups. Cambridge, MA: Harvard University Press.

Olzak, Susan. 1989. "Labor Unrest, Immigration, and Ethnic Conflict in Urban America, 18801914." American Journal of Sociology 94:1303-1333.

Pedriana, Nicholas \& Robin Stryker. 1997. "Employment Opportunity-Affirmative Action Law and the Philadelphia Plan." American Journal of Sociology 103(3):633-691.

Perline, M. \& V. Lorenz. 1970. "Factors Influencing Member Participation in Trate Union Activities." American Journal of Economics and Sociology 29:425-437.

Reitz, Jeffrey G. \& Anil Verma. 2004. "Immigration, Race, and Labor: Unionization and Wages in the Canadian Labor Market." Industrial Relations 43(4):835-854.

Riddell, Chris. 2004. "Union Certification Success Under Voting Versus Card-Check Procedures: Evidence from British Columbia, 1978-1998." Industrial and Labor Relations Review 57(4):493517.

Robinson, Corre, Tiffany Taylor, Donald Tomaskovic-Devey, Catherine Zimmer \& Matthew W. Irvine Jr. 2005. "Studying Race/Ethnic and Sex Segregation at the Establishment Level: Methodological Issues and Substantive Opportunities Using EEO-1 Reports." Work and Occupations 32:5-38.

Rooks, Daisy. 2004. Sticking It Out or Packing It In? Organizer Retention in the New Labor Movement. in Milkman \& Voss (2004).

Rosenfeld, Jake. 2014. What Unions No Longer Do. Cambridge, MA: Harvard University Press.

Rosenfeld, Jake \& Meredith Kleykamp. 2009. "Hispanics and Organized Labor in the United States, 1973 to 2007." American Sociological Review 74(6):916-937.

Rosenfeld, Jake \& Meredith Kleykamp. 2012. "Organized Labor and Racial Wage Inequality in the United States." American Journal of Sociology 117(5):1460-1502.

Sayles, L. R. \& G. Strauss. 1953. The Local Union: Its Place in the Industrial Plant. New York: Harper and Brothers.

Schuwerk, Robert P. 1972. "The Philadelphia Plan: A Study in the Dynamics of Executive Power." The University of Chicago Law Review 39(4):723-760.

Sharpe, Thresa. 2004. Union Democracy and Successful Campaigns: The Dynamics of Staff Authority and Worker Participation in an Organizing Union. In Rebuilding Labor: Organizing and Organizers in the New Union Movement, ed. Ruth Milkman \& Kim Voss. Ithaca, NY: ILR Press pp. 62-87.

Smith, Robert Michael. 2003. From Blackjacks to Briefcases: A History of Commercialized Strikebreaking and Unionbusting in the United States. Athens, OH: University of Ohio Press.

Snipp, Matthew C. 2003. "Racial Measurement in the American Census: Past Practices and Implications for the Future." Annual Review of Sociology 29:563-588.

Soule, Sarah A. 2009. Contention and Corporate Social Responsibility. Cambridge: Cambridge University Press.

Soule, Sarah A. \& Brayden G. King. 2006. "The Stages of the Policy Process and the Equal Rights Amendment, 1972-1982." American Journal of Sociology 111(6):1871-1909.

Soule, Sarah A. \& Christian Davenport. 2009. "Velvet Glove, Iron Fist or Even Hand? Protest Policing in the United States, 1960-1990." Mobilization 14:1-22. 
Stromquist, Shelton \& Marvin Bergman, eds. 1997. Unionizing the Jungles: Labor and Community in the Twentieth-Century Meatpacking Industry. Iowa City, IA: University of Iowa Press.

Tomaskovic-Devey, Donald, Catherine Zimmer, Kevin Stainback, Corre Robinson, Tiffany Taylor \& Tricia McTague. 2006. "Documenting Desegregation: Segregation in American Workplaces by Race, Ethnicity, and Sex, 1966-2003." American Sociological Review 71:565-588.

Tomlins, Christopher L. 1985. "The New Deal, Collective Bargaining, and the Triumph of Industrial Pluralism." Industrial and Labor Relations Review 39(1):19-34.

Tope, Daniel \& David Jacobs. 2009. "The Politics of Union Decline: The Contingent Determinants of Union Recognition Elections and Victories." American Sociological Review 74(5):842-864.

van Knippenberg, Daan \& Michaéla C. Schippers. 2007. "Work Group Diversity." Annual Review of Psychology 58:515-541.

Voss, Kim \& Rachel Sherman. 2000. "Breaking the Iron Law of Oligarchy: Union Revitalization in the American Labor Movement." American Journal of Sociology 106(2):303-350.

Wessels, Walter J. 1981. "Economic Effects of Right to Work Laws." Journal of Labor Research $2(1): 55-75$.

Widener, Daniel. 2008. "Another City is Possible: Interethnic Organizing in Contemporary Los Angeles." Race/Ethnicity 1(2):189-219.

Williams, Katherine Y. \& Charles A. O'Reilly. 1998. "Demography and Diversity in Organizations: A Review of 40 Years of Research." Research in Organizational Behavior 20:77-140.

Wilson, Jake B. 2008. "The Racialized Picket Line: White Workers and Racism in the Southern California Supermarket Strike." Critical Sociology 34(3):349-367.

Winship, Christopher \& Robert D. Mare. 1992. "Models for Sample Selection Bias." Annual Review of Sociology 18:327-350.

Yates, Charlotte A. B. 2005. "Segmented Labour, United Unions? How Unions in Canada Cope with Diversity." Transfer: European Review of Labour and Research 11(4):617-628.

Yu, Kyoung-Hee. 2008. Between Bureaucratic Organization and Social Movements: Careers in the Justice for Janitors Campaign PhD thesis Massachusetts Institute of Technology Cambridge, MA: .

Zeiger, Robert H. 1995. The CIO, 1935-1955. Chapel Hill, NC: University of North Carolina Press.

Zeiger, Robert H., ed. 1986. American Workers, American Unions, 1920-1985. Baltimore, MD: Johns Hopkins University Press. 
Table 1: Survival rates of organizing drives among homogeneous and heterogeneous work groups

\begin{tabular}{|c|c|c|c|c|}
\hline & $\begin{array}{c}\text { Filed } \\
\text { petitions }\end{array}$ & $\begin{array}{c}\text { Held } \\
\text { elections }\end{array}$ & $\begin{array}{c}\text { Won } \\
\text { elections }\end{array}$ & $\begin{array}{c}\text { Cumulative } \\
\text { survival rate }(\%)\end{array}$ \\
\hline Homogeneous units & 1125 & 824 & 435 & 38.7 \\
\hline Survival rate $(\%)$ & & 73.2 & 52.8 & \\
\hline Heterogeneous units & 6838 & 4115 & 2452 & 35.8 \\
\hline Survival rate (\%) & & 60.2 & 59.6 & \\
\hline Ratio, by stage & $1: 7.1$ & $1: 5.9$ & $1: 6.6$ & \\
\hline
\end{tabular}

All differences in survival rates are significant at $p<.05$. 
Table 2: Summary statistics for regressions

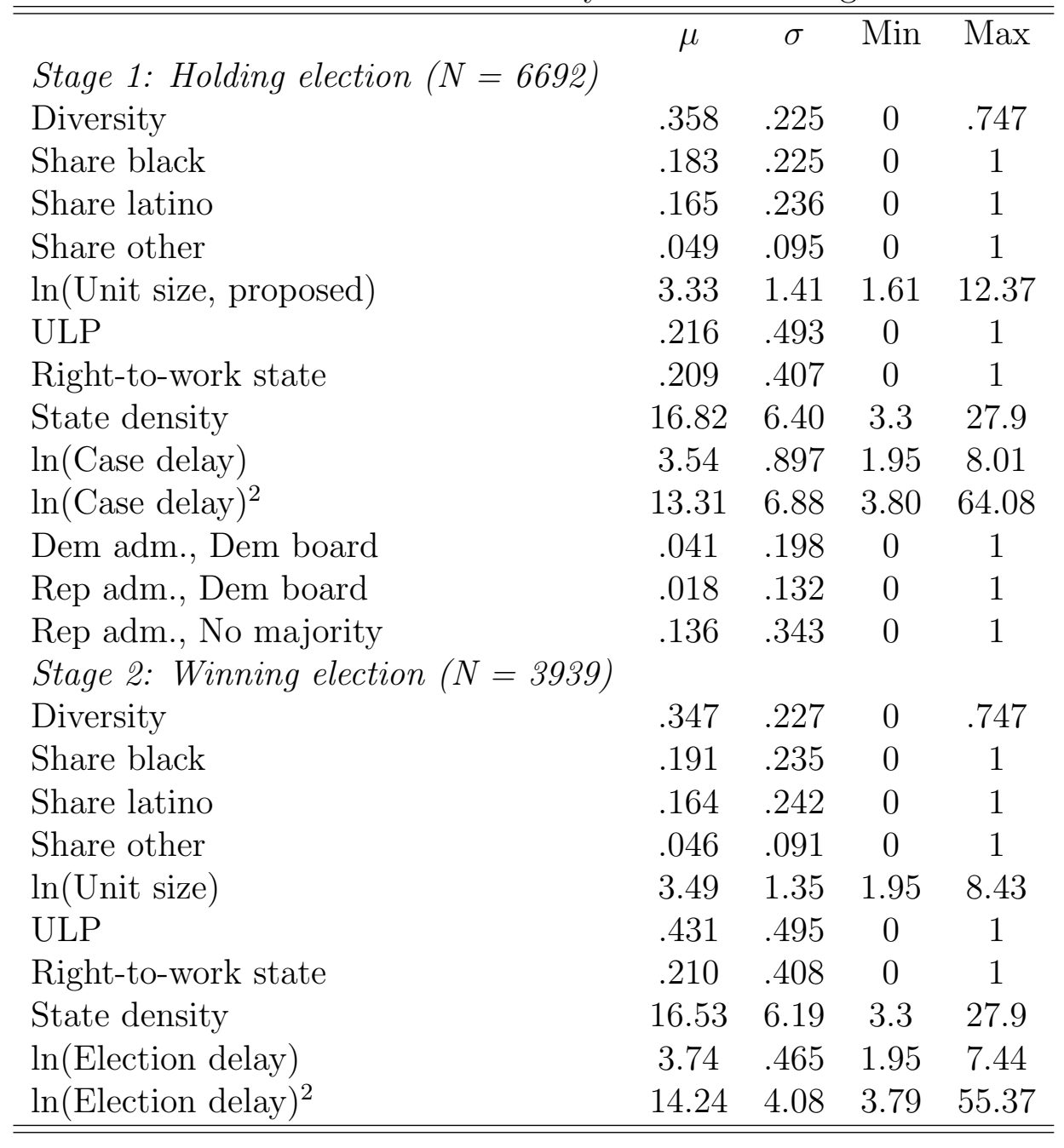


Table 3: Logistic models of diversity and minority shares of employment on holding and winning a union-representation election

\begin{tabular}{lcccc|cccc}
\hline \hline & \multicolumn{5}{c}{ Held } & \multicolumn{5}{c}{ Won } \\
& 1 & 2 & 3 & 4 & 5 & 6 & 7 & 8 \\
\hline Diversity & $-.487^{* *}$ & $-.728^{* *}$ & $-.518^{* *}$ & $-.430^{* *}$ & $.399^{* *}$ & .238 & $.438^{* *}$ & $.274^{\dagger}$ \\
& $(.108)$ & $(.118)$ & $(.112)$ & $(.117)$ & $(.138)$ & $(.148)$ & $(.142)$ & $(.149)$ \\
Share black & & $.653^{* *}$ & & & & $.439^{* *}$ & & \\
& & $(.122)$ & & & & $(.145)$ & & \\
Share latino & & & .111 & & & & -.144 & \\
& & & $(.107)$ & & & & $(.133)$ & \\
Share other & & & & -.352 & & & & $.812^{*}$ \\
& & & & $(.272)$ & & & & $(.377)$ \\
Constant & $.538^{* *}$ & $.507^{* *}$ & $.531^{* *}$ & $.535^{* *}$ & $.141^{*}$ & $.115^{*}$ & $.151^{* *}$ & $.147^{* *}$ \\
& $(.046)$ & $(.046)$ & $(.047)$ & $(.046)$ & $(.057)$ & $(.058)$ & $(.058)$ & $(.057)$ \\
\hline $\mathrm{N}$ & 7053 & 7053 & 7053 & 7053 & 4159 & 4159 & 4159 & 4159 \\
$\mathrm{LL}$ & -4764 & -4750 & -4764 & -4764 & -2838 & -2833 & -2838 & -2836 \\
\hline **: P $<.01, *: \mathrm{P}<.05, \dagger: \mathrm{P}<.1$ & & & & & &
\end{tabular}

"Other" includes the two categories "Asian or Pacific Islander" and "American Indian or Alaskan Native" as listed on EEO-1 survey forms. 
Table 4: Bivariate probit model of racial diversity's effect on holding and winning a union-representation election

\begin{tabular}{|c|c|c|c|c|}
\hline & 9 & 10 & 11 & 12 \\
\hline \multicolumn{5}{|l|}{ Holding election } \\
\hline Diversity & $\begin{array}{c}-.243^{* *} \\
(.071)\end{array}$ & $\begin{array}{c}-.395^{* *} \\
(.077)\end{array}$ & $\begin{array}{c}-.269^{* *} \\
(.074)\end{array}$ & $\begin{array}{c}-.222^{* *} \\
(.076)\end{array}$ \\
\hline Share black & & $\begin{array}{l}.417^{* *} \\
(.078)\end{array}$ & & \\
\hline Share latino & & & $\begin{array}{l}.086 \\
(.070)\end{array}$ & \\
\hline Share other & & & & $\begin{array}{l}-.147 \\
(.177)\end{array}$ \\
\hline Unit size (proposed) & $\begin{array}{l}.109^{* *} \\
(.011)\end{array}$ & $\begin{array}{l}.108^{* *} \\
(.011)\end{array}$ & $\begin{array}{l}.109^{* *} \\
(.011)\end{array}$ & $\begin{array}{l}.109^{* *} \\
(.011)\end{array}$ \\
\hline ULP & $\begin{array}{c}-.249^{* *} \\
(.082)\end{array}$ & $\begin{array}{c}-.242^{* *} \\
(.091)\end{array}$ & $\begin{array}{l}-.251^{*} \\
(.092)\end{array}$ & $\begin{array}{c}-.248^{*} \\
(.090)\end{array}$ \\
\hline Right-to-work state & $\begin{array}{c}-.149^{* *} \\
(.055)\end{array}$ & $\begin{array}{c}-.178^{* *} \\
(.056)\end{array}$ & $\begin{array}{c}-.149^{* *} \\
(.055)\end{array}$ & $\begin{array}{c}-.146^{* *} \\
(.056)\end{array}$ \\
\hline State density & $\begin{array}{c}-.013^{* *} \\
(.004)\end{array}$ & $\begin{array}{c}-.014^{* *} \\
(.004)\end{array}$ & $\begin{array}{c}-.014^{* *} \\
(.004)\end{array}$ & $\begin{array}{c}-.013^{* *} \\
(.004)\end{array}$ \\
\hline $\ln$ (Case delay) & $\begin{array}{l}.086^{* *} \\
(.031)\end{array}$ & $\begin{array}{l}.086^{* *} \\
(.032)\end{array}$ & $\begin{array}{c}.086^{* *} \\
(.032)\end{array}$ & $\begin{array}{c}.086^{* *} \\
(.32)\end{array}$ \\
\hline $\ln (\text { Case delay })^{2}$ & $\begin{array}{c}-.0016^{* *} \\
(.0003)\end{array}$ & $\begin{array}{c}-.0016^{* *} \\
(.0003)\end{array}$ & $\begin{array}{c}-.0016^{* *} \\
(.0003)\end{array}$ & $\begin{array}{c}-.0016^{* *} \\
(.0003)\end{array}$ \\
\hline Dem adm., Dem board & $\begin{array}{l}.131^{*} \\
(.067)\end{array}$ & $\begin{array}{l}.133^{*} \\
(.067)\end{array}$ & $\begin{array}{l}.135^{*} \\
(.067)\end{array}$ & $\begin{array}{l}.129^{\dagger} \\
(.067)\end{array}$ \\
\hline Rep adm., Dem board & $\begin{array}{l}.186^{\dagger} \\
(.105)\end{array}$ & $\begin{array}{l}.188^{\dagger} \\
(.106)\end{array}$ & $\begin{array}{l}.191^{\dagger} \\
(.105)\end{array}$ & $\begin{array}{l}.181^{\dagger} \\
(.106)\end{array}$ \\
\hline Rep adm., No majority & $\begin{array}{l}-.010 \\
(.037)\end{array}$ & $\begin{array}{l}-.007 \\
(.037)\end{array}$ & $\begin{array}{l}-.013 \\
(.037)\end{array}$ & $\begin{array}{l}-.008 \\
(.037)\end{array}$ \\
\hline Constant & $\begin{array}{l}.158^{\dagger} \\
(.082)\end{array}$ & $\begin{array}{l}.159^{\dagger} \\
(.082)\end{array}$ & $\begin{array}{l}.155^{\dagger} \\
(.082)\end{array}$ & $\begin{array}{l}.149^{\dagger} \\
(.082)\end{array}$ \\
\hline$\overline{\text { Winning élection }}{ }^{-}-$ & & & & \\
\hline Diversity & $\begin{array}{l}.017 \\
(.074)\end{array}$ & $\begin{array}{c}-.134^{\dagger} \\
(.078)\end{array}$ & $\begin{array}{c}.022 \\
(.076)\end{array}$ & $\begin{array}{l}.0001 \\
(.078)\end{array}$ \\
\hline Share black & & $\begin{array}{l}.419^{* *} \\
(.075)\end{array}$ & & \\
\hline Share latino & & & $\begin{array}{l}-.016 \\
(.070)\end{array}$ & \\
\hline Share other & & & & $\begin{array}{l}.123 \\
(.189)\end{array}$ \\
\hline Unit size & $\begin{array}{l}-.028^{*} \\
(.014)\end{array}$ & $\begin{array}{c}-.029^{*} \\
(.013)\end{array}$ & $\begin{array}{l}-.028^{*} \\
(.013)\end{array}$ & $\begin{array}{c}-.029^{*} \\
(.014)\end{array}$ \\
\hline ULP & $\begin{array}{l}.153^{* *} \\
(.033)\end{array}$ & $\begin{array}{l}.146^{* *} \\
(.033)\end{array}$ & $\begin{array}{l}.151^{* *} \\
(.033)\end{array}$ & $\begin{array}{l}.154^{* *} \\
(.034)\end{array}$ \\
\hline Right-to-work state & $\begin{array}{l}-.021 \\
(.058)\end{array}$ & $\begin{array}{l}-.054 \\
(.058)\end{array}$ & $\begin{array}{l}-.023 \\
(.058)\end{array}$ & $\begin{array}{l}-.022 \\
(.059)\end{array}$ \\
\hline State density & $\begin{array}{l}-.003 \\
(.004)\end{array}$ & $\begin{array}{l}-.004 \\
(.004)\end{array}$ & $\begin{array}{l}-.004 \\
(.004)\end{array}$ & $\begin{array}{l}-.004 \\
(.004)\end{array}$ \\
\hline $\ln$ (Election delay) & $\begin{array}{l}-.038^{*} \\
(.015)\end{array}$ & $\begin{array}{c}-.036^{*} \\
(.016)\end{array}$ & $\begin{array}{c}-.038^{*} \\
(.017)\end{array}$ & $\begin{array}{l}-.039^{*} \\
(.017)\end{array}$ \\
\hline $\ln (\text { Election delay })^{2}$ & $\begin{array}{l}.0008^{*} \\
(.0003)\end{array}$ & $\begin{array}{l}.0008^{*} \\
(.0004)\end{array}$ & $\begin{array}{l}.0009^{*} \\
(.0004)\end{array}$ & $\begin{array}{l}.0008^{*} \\
(.0004)\end{array}$ \\
\hline Constant & $\begin{array}{c}-.296^{* *} \\
(.085) \\
\end{array}$ & $\begin{array}{c}-.296^{* *} \\
(.085)\end{array}$ & $\begin{array}{c}-.295^{* *} \\
(.084)\end{array}$ & $\begin{array}{c}-.290^{* *} \\
(.086) \\
\end{array}$ \\
\hline LL & -7050 & -7032 & -7049 & -7049 \\
\hline$\rho$ & $.971^{* *}$ & $.974^{* *}$ & $.974^{* *}$ & $.966^{* *}$ \\
\hline
\end{tabular}


Table 5: Logistic models of the relationship between diversity the presence of an unfair labor practice charge

\begin{tabular}{|c|c|c|c|c|c|}
\hline & 13 & 14 & 15 & 16 & 17 \\
\hline Diversity & $\begin{array}{l}.416^{* *} \\
(.115)\end{array}$ & $\begin{array}{l}.257^{*} \\
(.128)\end{array}$ & $\begin{array}{l}.523^{* *} \\
(.122)\end{array}$ & $\begin{array}{l}.436^{* *} \\
(.116)\end{array}$ & $\begin{array}{l}.494^{* *} \\
(.148)\end{array}$ \\
\hline Share black & & $\begin{array}{l}.340^{* *} \\
(.119)\end{array}$ & & & \\
\hline Share latino & & & $\begin{array}{c}-.293^{* *} \\
(.110)\end{array}$ & & \\
\hline Share other & & & & $\begin{array}{l}-.002 \\
(.001)\end{array}$ & \\
\hline Unit size (proposed) & & & & & $\begin{array}{l}.171^{* *} \\
(.023)\end{array}$ \\
\hline Right-to-work state & & & & & $\begin{array}{c}.742 \\
(.916)\end{array}$ \\
\hline Dem adm., Dem board & & & & & $\begin{array}{c}.196 \\
(.149)\end{array}$ \\
\hline Rep adm., Dem board & & & & & $\begin{array}{l}.492^{*} \\
(.206)\end{array}$ \\
\hline Rep adm., No majority & & & & & $\begin{array}{l}-.024 \\
(.076)\end{array}$ \\
\hline 2-digit NAICS & & & & & $\mathrm{Y}$ \\
\hline Union & & & & & Y \\
\hline State & & & & & $\mathrm{Y}$ \\
\hline $\mathrm{N}$ & 7053 & 7053 & 7053 & 7053 & 6277 \\
\hline LL & -4778 & -4774 & -4775 & -4777 & -3879 \\
\hline
\end{tabular}

**: $\mathrm{P}<.01, *: \mathrm{P}<.05, \dagger: \mathrm{P}<.1$

Including share black, share latino, or share other as covariates in model 17 (available on request) produces comparable point estimates for diversity and comparable significance levels. Replicating models 13 through 16 on the sub-sample used in the fixed-effects specification of model 17 also produces similar results. 
Table 6: Fixed-effect bivariate probit models of holding and winning a unionrepresentation election

\begin{tabular}{|c|c|c|c|}
\hline & 18 & 19 & 20 \\
\hline \multicolumn{4}{|l|}{ Holding election } \\
\hline Diversity & $-.279^{* *}$ & $-.238^{* *}$ & $\begin{array}{l}-.141^{\dagger} \\
125)\end{array}$ \\
\hline \multirow{2}{*}{ Unit size (proposed) } & $.070^{* *}$ & $.064^{* *}$ & $.066^{* *}$ \\
\hline & $(.012)$ & $(.014)$ & $(.014)$ \\
\hline \multirow[t]{2}{*}{ ULP } & $-.298^{* *}$ & $-.198^{* *}$ & $-.143^{* *}$ \\
\hline & $(.033)$ & $(.036)$ & $(.036)$ \\
\hline \multirow[t]{2}{*}{ Right-to-work state } & $-.098^{\dagger}$ & -.032 & .045 \\
\hline & $(.057)$ & $(.063)$ & $(.087)$ \\
\hline \multirow[t]{2}{*}{ State density } & $-.013^{* *}$ & $-.008^{\dagger}$ & -.007 \\
\hline & $(.004)$ & $(.004)$ & $(.005)$ \\
\hline \multirow[t]{2}{*}{$\ln$ (Case delay) } & $.012^{* *}$ & $.015^{* *}$ & $.002^{* *}$ \\
\hline & $(.003)$ & $(.003)$ & $(.0003)$ \\
\hline \multirow[t]{2}{*}{$\ln (\text { Case delay })^{2}$} & $-.0019^{* *}$ & $-.0020^{* *}$ & $-.0020^{* *}$ \\
\hline & $(.0003)$ & $(.0003)$ & $(.0003)$ \\
\hline \multirow[t]{2}{*}{ Dem adm., Dem board } & .106 & .103 & .089 \\
\hline & $(.074)$ & $(.089)$ & $(.091)$ \\
\hline \multirow[t]{2}{*}{ Rep adm., Rep board } & $.193^{\dagger}$ & $.209^{\dagger}$ & .197 \\
\hline & $(.113)$ & $(.128)$ & $(.129)$ \\
\hline \multirow[t]{2}{*}{ Rep adm., No majority } & -.012 & -.026 & -.027 \\
\hline & $(.047)$ & $(.050)$ & $(.049)$ \\
\hline 2-digit NAICS & yes & yes & yes \\
\hline \multicolumn{2}{|l|}{ Union } & yes & yes \\
\hline \multicolumn{2}{|l|}{ Region } & & yes \\
\hline \multirow[t]{2}{*}{ Constant } & .219 & .030 & .013 \\
\hline & $(.338)$ & $(.373)$ & $(.384)$ \\
\hline \multicolumn{4}{|l|}{ Winning election } \\
\hline \multirow[t]{2}{*}{ Diversity } & .048 & .048 & .049 \\
\hline & $(.107)$ & $(.106)$ & $(.103)$ \\
\hline \multirow[t]{2}{*}{ Unit size } & $-.077^{*}$ & $-.116^{* *}$ & $-.117^{* *}$ \\
\hline & $(.030)$ & $(.029)$ & $(.028)$ \\
\hline \multirow[t]{2}{*}{ ULP } & $.146^{* *}$ & $.122^{* *}$ & $.125^{* *}$ \\
\hline & $(.040)$ & $(.044)$ & $(.044)$ \\
\hline \multirow[t]{2}{*}{ Right-to-work state } & .026 & .078 & .171 \\
\hline & $(.068)$ & $(.075)$ & $(.104)$ \\
\hline \multirow[t]{2}{*}{ State density } & -.003 & .000 & -.001 \\
\hline & $(.005)$ & $(.005)$ & $(.006)$ \\
\hline \multirow[t]{2}{*}{$\ln$ (Election delay) } & -.005 & $-.002^{*}$ & $-.015^{*}$ \\
\hline & $(.005)$ & $(.001)$ & $(.007)$ \\
\hline \multirow[t]{2}{*}{$\ln (\text { Election delay })^{2}$} & -.0006 & -.0007 & -.0002 \\
\hline & $(.0005)$ & $(.0007)$ & $(.0007)$ \\
\hline 2-digit NAICS & yes & yes & yes \\
\hline \multicolumn{2}{|l|}{ Union } & yes & yes \\
\hline Region & & & yes \\
\hline Constant & -.080 & -.078 & -.127 \\
\hline & $(.406)$ & $(.480)$ & $(.482)$ \\
\hline $\mathrm{N}$ & 6692 & 5866 & 5866 \\
\hline LL & -6915 & -5907 & -5893 \\
\hline$\rho$ & $.809^{*}$ & $.685^{*}$ & $.694^{*}$ \\
\hline
\end{tabular}

**: $\mathrm{P}<.01,{ }^{*}: \mathrm{P}<.05, \dagger: \mathrm{P}<.1$ 
Table 7: Correlation of error terms $(\rho)$ in bivariate probit models of holding and winning representation elections, estimated for different regions

\begin{tabular}{lc}
\hline \hline & $\rho$ \\
\hline Northeast & $.924^{* *}$ \\
& $(.290)$ \\
Midwest & $.787^{* *}$ \\
& $(.323)$ \\
South & .211 \\
& $(.189)$ \\
Plains & .188 \\
& $(.180)$ \\
Mountain West & $.751^{\dagger}$ \\
& $(.388)$ \\
Pacific Coast & $.877^{* *}$ \\
& $(.355)$ \\
\hline Pooled national & $.902^{* *}$ \\
& $(.306)$ \\
\hline
\end{tabular}

$\overline{* *: \mathrm{P}<.01, *: \mathrm{P}<.05, \dagger: \mathrm{P}}<.1$

Northeast: CT, DE, MA, MD, ME, NH, NJ, NY, PA, RI, VT

Midwest: IL, IN, KY, MI, MN, OH, WI, WV

South: AL, AR, FL, GA, LA, MS, NC, SC, TN, TX, VA

Plains: IA, KS, MI, ND, NE, OK, SD

Mountain West: AZ, CO, ID, NM, MT, UT, WY

Pacific Coast: AK, CA, HI, NV, OR, WA 
Table 8: Logistic models of diversity and minority shares of employment on holding and winning a union-representation election, using all non-managerial establishment workers to calculate variables

\begin{tabular}{|c|c|c|c|c|c|c|c|c|}
\hline & \multicolumn{3}{|c|}{ Held } & \multicolumn{2}{|c|}{ Won } & \multirow[b]{2}{*}{ A6 } & \multirow[b]{2}{*}{ A7 } & \multirow[b]{2}{*}{ A8 } \\
\hline & A1 & A2 & A3 & $\mathrm{A} 4^{\ddagger}$ & A5 & & & \\
\hline Diversity & $\begin{array}{c}.106^{\dagger} \\
(.061)\end{array}$ & $\begin{array}{c}-.956^{* *} \\
(.120)\end{array}$ & $\begin{array}{c}.629^{* *} \\
(.118)\end{array}$ & $\begin{array}{c}1.103^{* *} \\
(.123)\end{array}$ & $\begin{array}{l}.487^{* *} \\
(.144)\end{array}$ & $\begin{array}{l}.481^{* *} \\
(.145)\end{array}$ & $\begin{array}{l}.475^{* *} \\
(.144)\end{array}$ & $\begin{array}{l}.489^{*} \\
(.144)\end{array}$ \\
\hline Share black & & $\begin{array}{c}1.024^{* *} \\
(.082)\end{array}$ & & & & $\begin{array}{c}.003 \\
(.007)\end{array}$ & & \\
\hline Share latino & & & $\begin{array}{c}.915 \\
(.079)\end{array}$ & & & & $\begin{array}{c}.006 \\
(.007)\end{array}$ & \\
\hline Share other & & & & $\begin{array}{c}-1.785^{* *} \\
(.103)\end{array}$ & & & & $\begin{array}{c}-.001 \\
(.001)\end{array}$ \\
\hline Constant & $\begin{array}{l}.101^{\dagger} \\
(.061)\end{array}$ & $\begin{array}{l}.405^{* *} \\
(.048)\end{array}$ & $\begin{array}{l}.360^{* *} \\
(.048)\end{array}$ & $\begin{array}{c}-.257^{* *} \\
(.053)\end{array}$ & $\begin{array}{c}.101^{\dagger} \\
(.061)\end{array}$ & $\begin{array}{l}.101^{\dagger} \\
(.061)\end{array}$ & $\begin{array}{l}.101^{\dagger} \\
(.061)\end{array}$ & $\begin{array}{c}.097 \\
(.061)\end{array}$ \\
\hline $\mathrm{N}$ & 7053 & 7053 & 7053 & 7053 & 4159 & 4159 & 4159 & 4159 \\
\hline LL & -4774 & -4551 & -4632 & -4081 & -2837 & -2837 & -2836 & -2837 \\
\hline
\end{tabular}

**: $\mathrm{P}<.01,{ }^{*}: \mathrm{P}<.05, \dagger: \mathrm{P}<.1$

‡: Model does not converge.

"Other" includes the two categories "Asian or Pacific Islander" and "American Indian or Alaskan Native" as listed on EEO-1 survey forms. 
Table 9: Bivariate probit model of racial diversity's effect on holding and winning a union-representation election, using all non-managerial establishment workers to calculate variables

\begin{tabular}{|c|c|c|c|c|}
\hline & A9 & A10 & A11 & $\mathrm{A} 12$ \\
\hline \multicolumn{5}{|l|}{ Holding election } \\
\hline \multirow[t]{2}{*}{ Diversity } & .009 & $-.059^{*}$ & $-.049^{* *}$ & $.611^{* *}$ \\
\hline & $(.073)$ & $(.024)$ & $(.023)$ & $(.084)$ \\
\hline \multirow[t]{2}{*}{ Share black } & & $.178^{*}$ & & \\
\hline & & $(.082)$ & & \\
\hline \multirow[t]{2}{*}{ Share latino } & & & $-.135^{\dagger}$ & \\
\hline & & & $(.074)$ & \\
\hline \multirow[t]{2}{*}{ Share other } & & & & $-3.197^{* *}$ \\
\hline & & & & $(.100)$ \\
\hline \multirow[t]{2}{*}{ Unit size (proposed) } & $.107^{* *}$ & $.107^{* *}$ & $.107^{* *}$ & $.105^{* *}$ \\
\hline & $(.011)$ & $(.011)$ & $(.011)$ & $(.013)$ \\
\hline \multirow[t]{2}{*}{ ULP } & $-.249^{* *}$ & $-.246^{* *}$ & $-.248^{*}$ & -.021 \\
\hline & $(.083)$ & $(.101)$ & $(.112)$ & $(.036)$ \\
\hline \multirow[t]{2}{*}{ Right-to-work state } & $-.186^{* *}$ & $-.197^{* *}$ & $-.185^{* *}$ & $-.280^{* *}$ \\
\hline & $(.056)$ & $(.056)$ & $(.056)$ & $(.063)$ \\
\hline \multirow[t]{2}{*}{ State density } & $-.017^{* *}$ & $-.017^{* *}$ & $-.016^{* *}$ & $-.021^{* *}$ \\
\hline & $(.004)$ & $(.004)$ & $(.004)$ & $(.004)$ \\
\hline \multirow[t]{2}{*}{$\ln ($ Case delay $)$} & $.084^{* *}$ & $.084^{* *}$ & $.085^{* *}$ & $.061^{\dagger}$ \\
\hline & $(.032)$ & $(.032)$ & $(.032)$ & $(.35)$ \\
\hline \multirow[t]{2}{*}{$\ln (\text { Case delay })^{2}$} & $-.0016^{* *}$ & $-.0016^{* *}$ & $-.0016^{* *}$ & $-.0015^{* *}$ \\
\hline & $(.0003)$ & $(.0004)$ & $(.0003)$ & $(.0004)$ \\
\hline \multirow[t]{2}{*}{ Dem adm., Dem board } & $.128^{\dagger}$ & $.130^{\dagger}$ & $.125^{\dagger}$ & .105 \\
\hline & $(.067)$ & $(.067)$ & $(.066)$ & $(.092)$ \\
\hline \multirow[t]{2}{*}{ Rep adm., Dem board } & $.188^{\dagger}$ & $.190^{\dagger}$ & $.186^{\dagger}$ & .097 \\
\hline & $(.106)$ & $(.106)$ & $(.106)$ & $(.134)$ \\
\hline \multirow[t]{2}{*}{ Rep adm., No majority } & -.008 & -.008 & -.009 & .097 \\
\hline & $(.036)$ & $(.037)$ & $(.036)$ & $(.051)$ \\
\hline \multirow[t]{2}{*}{ Constant } & $.135^{\dagger}$ & $.136^{\dagger}$ & $.137^{\dagger}$ & $-.177^{\dagger}$ \\
\hline & $(.081)$ & $\underline{(.082)}$ & $\underline{(.081)}$ & $(.094)$ \\
\hline \multicolumn{5}{|l|}{ 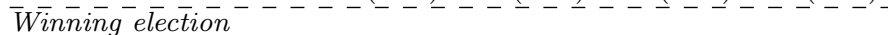 } \\
\hline \multirow[t]{2}{*}{ Diversity } & $.211^{* *}$ & .100 & $.267^{* *}$ & $.351^{* *}$ \\
\hline & $(.076)$ & $(.083)$ & $(.079)$ & $(.102)$ \\
\hline \multirow[t]{2}{*}{ Share black } & & $.287^{* *}$ & & \\
\hline & & $(.084)$ & & \\
\hline \multirow[t]{2}{*}{ Share latino } & & & $-.174^{*}$ & \\
\hline & & & $(.076)$ & \\
\hline Share other & & & & -.118 \\
\hline & & & & $(.164)$ \\
\hline Unit size & $-.029^{*}$ & $-.030^{*}$ & $-.027^{*}$ & $-.130^{* *}$ \\
\hline & $(.013)$ & $(.013)$ & $(.011)$ & $(.017)$ \\
\hline ULP & $.149^{* *}$ & $.148^{* *}$ & $.144^{* *}$ & $.188^{* *}$ \\
\hline & $(.034)$ & $(.033)$ & $(.032)$ & $(.041)$ \\
\hline Right-to-work state & -.055 & -.072 & -.055 & .083 \\
\hline & $(.058)$ & $(.058)$ & $(.057)$ & $(.076)$ \\
\hline State density & -.006 & $-.006^{\dagger}$ & $-.006^{\dagger}$ & .006 \\
\hline & $(.004)$ & $(.004)$ & $(.004)$ & $(.005)$ \\
\hline $\ln ($ Election delay) & $-.037^{*}$ & $-.038^{*}$ & $-.036^{*}$ & $-.001^{*}$ \\
\hline & $(.015)$ & $(.016)$ & $(.017)$ & $(.0005)$ \\
\hline $\ln (\text { Election delay })^{2}$ & $.0008^{*}$ & $.0008^{*}$ & $.0009^{*}$ & .0004 \\
\hline & $(.0004)$ & $(.0004)$ & $(.0004)$ & $(.0005)$ \\
\hline Constant & $-.313^{* *}$ & $-.310^{* *}$ & $-.311^{* *}$ & $.274^{\dagger}$ \\
\hline & $(.085)$ & $(.085)$ & $(.083)$ & $(.163)$ \\
\hline LL & -7054 & -7049 & -7052 & -6109 \\
\hline$\rho$ & $.982^{* *}$ & $.970^{* *}$ & $.999^{* *}$ & .162 \\
\hline
\end{tabular}




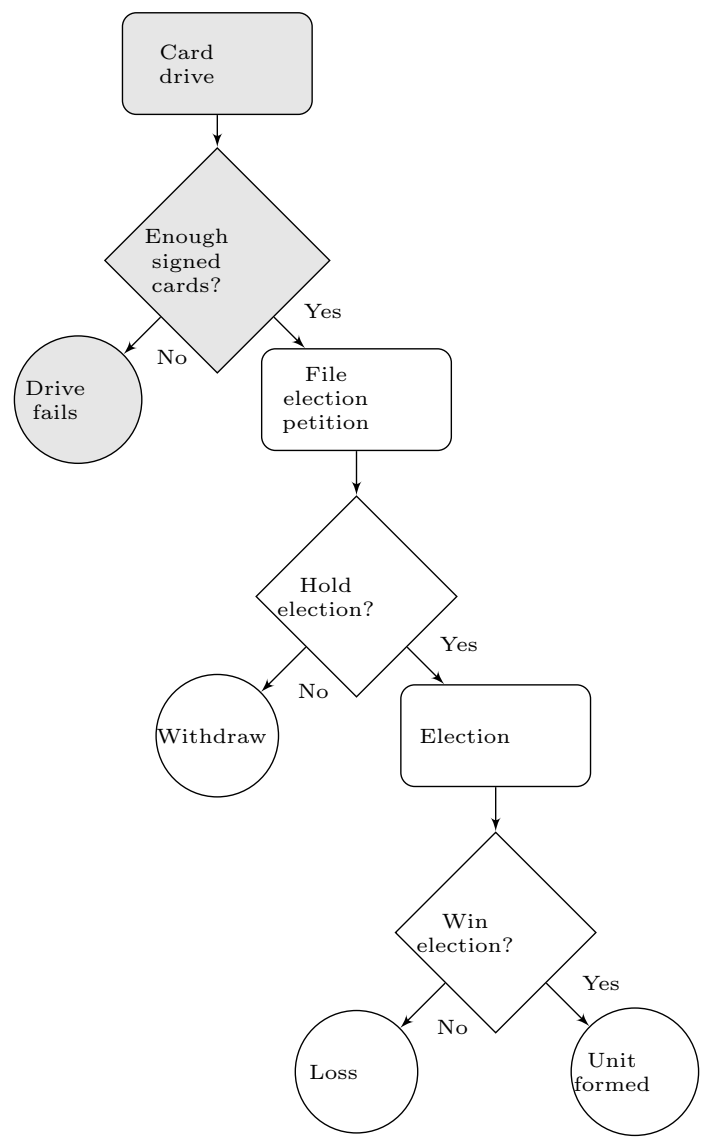

Figure 1: The union organizing process. Grey nodes are unobserved in these data. 